総 説

\title{
危険性の高いプラークの内膜剥離術の留意点
}

\author{
吉本 哲之，金子 貞男
}

\section{Tips in Carotid Endarterectomy for the Vulnerable Plaque}

Tetsuyuki Yoshimoto, M.D. and Sadao Kaneko, M.D.

Kashiwaba Neurosurgical Hospital, Sapporo, Hokkaido, Japan

Summary: The vulnerable plaque associated with motion of intraplaque contents plays an important role symptomatic carotid stenosis. Embolic stroke often recurs and can worsen in prognosis. Carotid endarterectomy is mainly selected for the surgical treatment to avoid embolic risk. However, care must also be taken in the surgical procedure to avoid risk.

\author{
Key words: \\ $\cdot$ vulnerable plaque \\ - embolus \\ $\cdot$ echo \\ - CEA
}

Surg Cereb Stroke

(Jpn) 41: 325-328, 2013

\section{はじめに}

症候性内頝動脈狭窄の診断におけるプラークの質的評価 は病態の解明や治療法の検討に非常に重要である.ささらに 近年, エコーや MRI などによるプラーク診断の進歩は, 質的診断の向上に寄与し複雑な病態の解明を可能にしてい る.これらの検査上，危険性が高いと評価されたプラーク は薄い繊維性皮膜下に脂質コアやプラーク内出血を主体と するために概して柔らかく, 潰瘍を合併することが多いた め再塞栓性のポテンシャルが高いことから不安定性プラー クと呼ばれる ${ }^{9)}$ 。これらのプラークは一般にCT で低吸収 域, MRIでは T1, T2 強調画像ともに高信号を呈し, ま たエコーでは低エコー信号を呈することにより，診断が可 能であり ${ }^{10)}$, これらの精查によって再塞栓性の危険性を把 握し, より再塞栓性の予防効果の高い治療を選択すること が可能となる.
エコー検査は石灰化を伴う場合にはその性状の正確な判 定は困難になるが, 他の検査と比較し, 動的な細部の性状 評価を行うことができる．われわれは以前よりエコー検査 上血管の拍動と異なるプラーク内部の主に長軸方向への動 きとそれに伴う上皮の陥凹をプラークの “摇動性”として とらえ, それに認められる特徵的な病態や再発リスク, 予 後などの検討を加え, その臨床像の重要性を唱えてきた ${ }^{4}$. 今回はその摇動性プラークの臨床的特徵についてまとめ, その上で外科的加療における留意点について検討を加えた ので報告する.

\section{摇動性プラーク \\ (motion of intraplaque contents) (Fig. 1)}

摇動性プラークとは顤動脈プラークの内部の構造物が血 管の拍動と位相を異にして長軸方向に動くプラークのこと であり，プラーク内部の動きに注目した用語である．拍動 


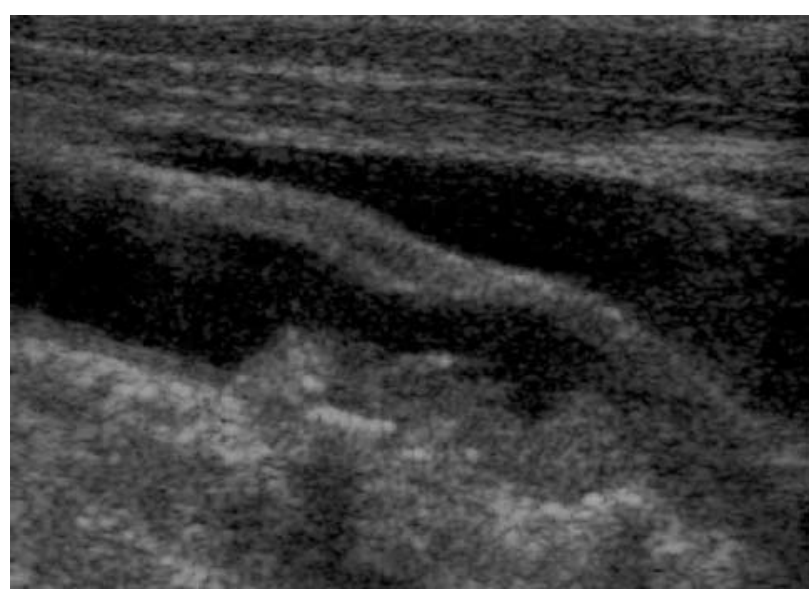

Fig. 1 Ultrasound sonography shows a typical view of "motion of the intraplaque contents."

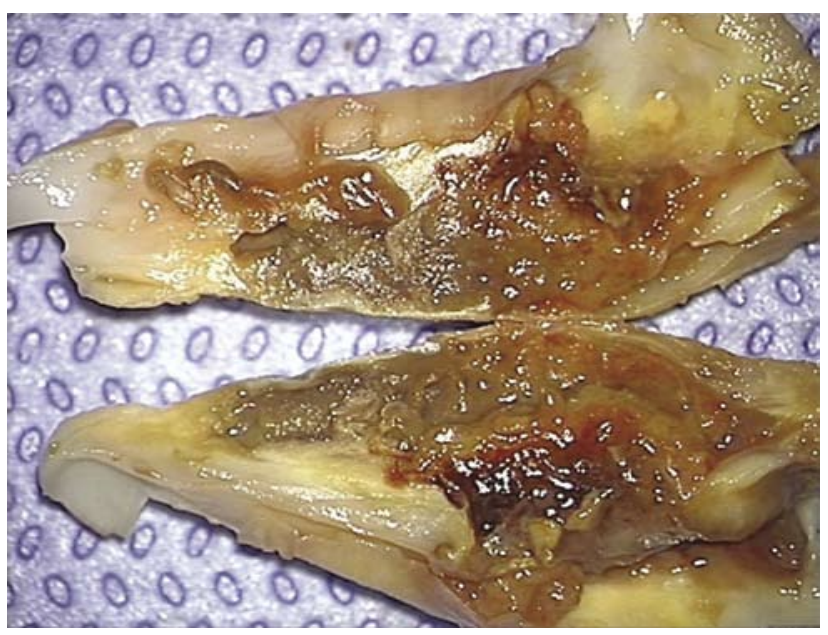

Fig. 2 An operative finding of a plaque sample, showing motion of the intraplaque contents on echo, harvested by CEA.

と異相性であることは拍動の動きが波打つように伝わる柔 らかな組織であることを示し，またそれに伴いその上皮が 陷凹する動きを呈している ${ }^{4)}$. エコー所見に基づいた不安 定性プラークの評価の報告は少な( ${ }^{3) 5 / 8)}$. Ogata らは可動 性プラークを 4 つに分類し, ulcer に向うプラークの拍動 性移動を fluctuating-ulcer-type としている8).われわれの 摇動性プラークの所見に重なる部分もあるが, 摇動性プ ラークは mobile plaque ではなく, plaque 内部の長軸方 向の動きに着眼している点で異なると考えている. 不安定 性プラークのエコー所見の特徵としては heterogenous な low echogenicity が多く, 上皮の陷凹とともに, 多くの場 合に上皮の欠落(潰瘍構造) を認める ${ }^{1226) 7}$. 狭窄の程度や 石灰化の合併はさまざまである.内膜剥離術で摘出した摇 動性プラークの標本を観察すると, プラーク内部は一部に

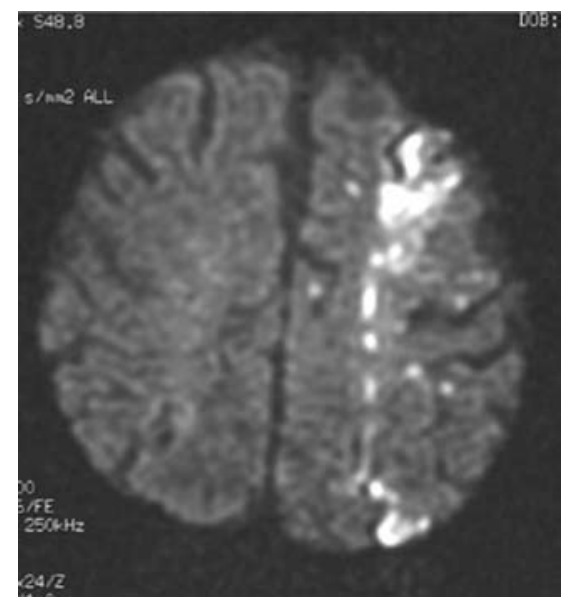

Fig. $3 \mathrm{MRI}$ DWI shows scattered high intensity spots as lining on the watershed zone, involving the cortical surfaces.

出血が混在し, 変性した lipid-rich な内容物が多く, 泥状 化している場合も認められる。この内容物が潰瘍部より血 管内腔に突出し, 遊離する直前の状態で認められることも あり，塞栓症の原因となることがうかがえる(Fig. 2).

症候性内澒動脈狭窄の中でエコー検査上摇動性プラーク を呈する症例は少なくなく, その病態像や臨床像に非常に 特徵を有している．摇動性プラークの発生頻度は以前のわ れわれの検討では脳梗塞連続 1,789 例中症候性内澒動脈狭 窄 147 例で, その中の 86 例 (58.5\%) 約半数以上に摇動性プ ラークの病態への関与が認められた ${ }^{4)}$. 特徵的な病態像は 発症時 MRI の所見に多く認められる散在性多発性脳梗塞 である. 塞栓源としては摇動性プラークがその塞栓源とな ることが多く，プラーク上皮の久損を通り摇動性プラーク 内部の物質が血流によって飛来し塞栓することは容易に考 えられうるが, 高度狭窄や潰瘍病変に伴う血栓形成による artery to artery 塞栓も原因となりうる.この病態を呈す る脳梗塞は MRI 上散在性に認められるが, 非常に細かな 粒子として塞栓するため, 病巣が媣部大脳白質, いわゆる watershed zone に起こることも多く認められる(Fig. 3). あたかも画像所見より hemodynamic compromise な原因 と考えやすいが, 大脳皮質に梗塞巣が存在することが特徵 である ${ }^{11)}$.

また，その予後も 1 つの臨床的特徵であり，われわれの 検討では, 症候性内澒動脈狭窄症の中で摇動性プラークを 有する患者の予後が有意に悪かったことが認められてい $ろ^{4)}$. 摇動性プラークからの脳塞栓症の診断下でへパリン を用いた急性期保存的加療中にエコー検査上プラーク内の 内容物の減少と MRI 上新たな梗塞巣の出現を経験するこ とが多い，そのため, 摇動性プラークを有する場合の保存 

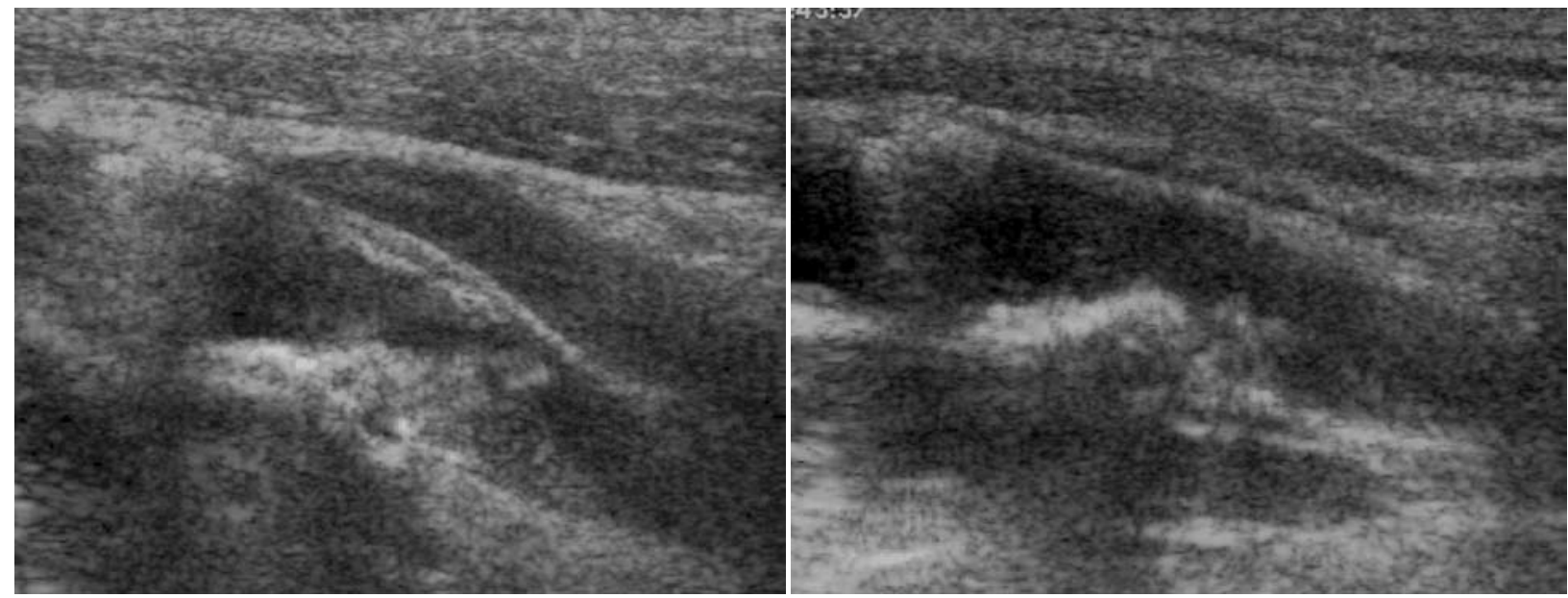

Fig. 4 A: Ultrasound sonography showed motion of the intraplaque contents.

B: The same view taken after two weeks showed the decreased contents.

A $\mid \mathbf{B}$

的加療中における再発性について検討を行った。

\section{摇動性プラークによる再塞栓性の検討}

対象は 2010 年から 2012 年に脳梗塞で当科入院となった 症候性内頚動脈狭窄症のうち入院時のエコー検査において 摇動性プラークを認めた 23 例である。 入院時の MRI DWI (diffusion weighted image)ですべて梗塞巣は散在 性を呈していた，当院の症候性内頚動脈狭窄性病変に対す る治療のプロトコールに従い入院後の加療は ACT（活性 化全凝固時間)のコントロール下にヘパリンを用いて保存 的に行い, 約 3 週後の脳血流評価の結果を踏まえて内膜剝 離術などの血行再建術を行っている. 方法はその保存的加 療期間中に行われたエコー所見で入院時に認められた摇動 性プラークの変化を観察することである。結果, 23 人中 9 人 (39\%)において 3 週間以内に摇動性プラークの内容物は 明らかに減少しており，それによりエコー上潰瘍形成の程 度が明瞭になっていた(Fig. 4A，B)。それに伴い MRI DWI ではほとんどの症例で新たな梗塞巣の増加を認めら れたが，症候性は少なくほとんどが無症候性であった。こ れらの結果から，ヘパリンによる保存的加療は再発抑制の 効果は低く, 約 $40 \%$ の頻度で発症 3 週間の短期間で再発 を起こしやすいことが明らかになった。

このように症候性内䅡動脈狭窄症の中で摇動性プラーク の場合には上記のような病態的特徵を有するため，その治 療については夕イミングや治療法など十分に検討する必要 がある。

\section{Surgical option について}

摇動性プラークの内䅡動脈狭窄症の治療選択(CEA or

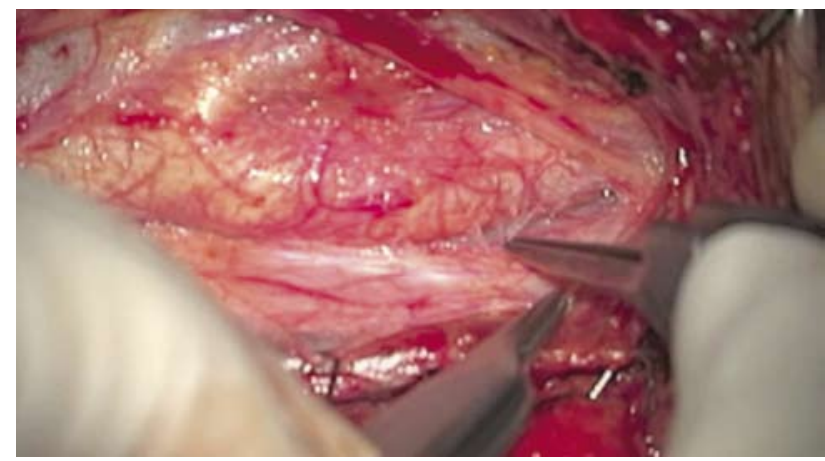

Fig. 5 The operative finding of CEA. The distal side of the internal carotid artery was dissected, avoiding being touched itself.

CAS) はそのプラークが非常に fragile であることが重要な ポイントである。最近では血管内治療においてもフィル ターやバルーンなど，さまざまなデバイスを駆使し術中塞 栓予防しているが，それに相反して䅡動脈の遮断に伴う術 中虚血の危険性は存在する。そのため治療の安全性や確実 性を考慮し CEA が first choice になると考えている。し かし，CEAにおいても操作中に打ける術中塞栓は十分に 危険性があり注意しなければならない.

\section{CEA のポイント}

$\mathrm{CAE}$ の術中塞栓を防ぐ最大のポイントは露出や確保の 際に“むやみに内頝動脈に触らない”ことである。CEA において近位や遠位の澒動脈の確保は必須であるが，露出 された頚動脈全長にわたる全周性の確保の必要性はない. 全周性の確保(頝動脈の裏側の剝離) は総䅡動脈近位端と内 
䅡動脈遠位端で血管テープを通す部分のみで十分であり， その剥離の際でも直接血管には触らず，シースを優しく持 ち上げ，ゆっくりと最小限に裏側を剥離することが大切で ある(Fig. 5)。外颈動脈確保の際も全周性に剥離する必要 はない. 頚動脈の裏面を剝離しないことによって, 術後の 下位脳神経の麻痺による嗄声や嚥下障害の危険性も減少す る.ささらに重度の摇動性プラークで塞栓物質がすでに内腔 に浮遊し, 塞栓の飛来の危険性がより高いと危惧された場 合には, 総䅡動脈近位側と外䅡動脈のごく短時間の一時遮 断を行い，確保のための永離を進める場合もある。この場 合には総頝動脈側の遮断のみでは不十分である。また，術 前の 3D-CT などにより, 頚動脈分岐部近位の裏側より動 脈の分枝が確認されている場合には, 内シャントチューブ を挿入後, その部分の剥離, 遮断を行うことで, 処置は可 能である。

われわれは CEA の際, 術中の虚血をなるべく最小限に とどめるため, 内シャントチューブを基本的に全例に使用 している. 頚動脈の露出範囲の決定やチューブの挿入にお ける動脈内のプラークの位置関係, 特に内頝動脈側の遠位 端の位置が重要になる.内䅡動脈の硬さを触知することに よりプラーク位置の判別は可能であるが，摇動性プラーク の場合には触ることにより塞栓の飛来の危険性があるた め，われわれは食道用エコープローブを軽くあて，エコー 下にプラークの進展の範囲を認識している。 このエコープ ローブは小さいため分岐部がより高位置の場合でも使用す ることが可能であり, 有用である. また, 剝離後血管縫合 後に内腔に浮遊しているプラークの取り残しなどを観察す ることができるため, 術直後の検査としても用いることが できる.

内シャントチューブの挿入は頚動脈の近位端と遠位端の みの小切開で挿入する。 これにより摘出するプラークを潰 瘍病変や摇動性部分などプラーク本体を傷めず，摘出する ことができ，その後プラークの細かな観察が可能となる。

最後に治療のタイミングであるが, 今回の検討では摇動 性プラークの場合, 3 週間以内の再梗塞が画像上約 $40 \%$ に認められ， 3 週以降の待機手術の危険性を示唆している と思われる. 狭窄度の低い場合には待機せず早期に行うこ とにより再発の危険性を減らせることが可能となるが, 高 度狭窄の場合には術後の hypereperfusion についても考慮 しなければならない，その予防的血流評価は梗塞後脳血流 の安定する発症後約 3 週以降に行われるため, それまでの 保存的治療の間の再梗塞のリスクが存在する. 明確なプロ トコールを描くことは困難だが, 症例ごと再発のリスクと hyperperfusionのリスクを評価し, crescendo ischemic attack など臨床所見やエコーなどの検査上の塞栓物質の 状態などを総合的に検討して，時機を冕しないように手術 のタイミングを決めるべきである.

\section{まと め}

われわれの提唱している脆弱なプラーク（摇動性プラー ク)の特徵は, 症候性内澒動脈の約半数に存在し, 空間的, 時間的多発性な梗塞を起こし, 保存的治療に難治性で再塞 栓の危険性が高いことがあげられる，それらの危険性を考 慮して治療法としては内膜剝離術が第一選択となるが, 術 中の塞栓を避けるための内䅡動脈の接触を極力最小限にす る“触らないCEA”が重要であり，その治療法とその夕 イミングには十分な検討が必要である.

\section{文献}

1) Eliasziw M, Streifler JY, Fox AJ, et al: Significance of plaque ulceration in symptomatic patients with highgrade carotid stenosis. North American Symptomatic Carotid Endarterectomy trial. Stroke 25: 304-308, 1944

2) Fisher M, Paganini-Hill A, Martin A, et al: Carotid plaque pathology: thrombosis, ulceration, and strole pathogenesis. Stroke 36: 253-257, 2005

3) Hill SL, Brozyna W: Extensive mobile thrombus of the internal carotid artery: a case report, treatment options, and a review of the literature. Am Surg 71: 853-855, 2005

4) Kashiwazaki D, Yoshimoto $\mathrm{T}$, Mikami $\mathrm{T}$, et al: Identification of high-risk carotid artery stenosis: motion of intraplaque contents detected using B-mode ultrasonography. J Neurosurg 117: 574-578, 2012

5) Lenzi GL, Vicentini E: The ruler is dead: an analysis of carotid plaque motion. Cerebrovasc Dis 23: 121-125, 2007

6) Morgenstein LB, Fox AJ, Sharpe BL, et al: The risks and benefits of carotid endarterectomy in patients with near occlusion for the carotid artery. Neurology 48: 911-915, 1997

7) Muraki M, Mikami T, Yoshimoto $\mathrm{T}$, et al: New criteria for the sonographic diagnosis of a plaque ulcer in the extracranial carotid artery. AJR Am J Roentgenol 198: 1161-1166, 2012

8) Ogata T, Yasaka M, Wakugawa Y, et al: Morphological classification of mobile plaques and their association with the early recurrent stroke. Cerebrovasc Dis 30(6): 606-611, 2010

9) Pelisek J, Eckstein HH, Zernecke A: Pathophysiological mechanisms of carotid plaque vulnerability: Impact on ischemic stroke. Arch Immunol Ther Exp 60(6): 431-442, 2012

10) Sasaki M: Plaque imaging for stenotic lesions of the cervical carotid artery. No Shinkei Geka 40(7): 579-584, 2012 (Japanese)

11) Yong SW, Bang OY, Lee PH, et al: Internal and cortical border-zone infarction: Clinical and diffusion-weighted imaging features. Stroke 37: 841-846, 2006 